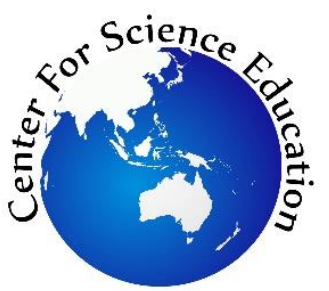

\author{
Tersedia online di EDUSAINS \\ Website: http://journal.uinjkt.ac.id/index.php/edusains
}

EDUSAINS, 13(1), 2020, 35-45

Research Artikel

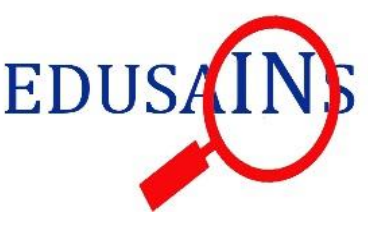

\title{
PENGEMBANGAN ENSIKLOPEDIA IPA BERBASIS INTEGRASI-INTERKONEKSI ISLAM-SAINS SEBAGAI SUMBER BELAJAR MANDIRI PESERTA DIDIK MADRASAH TSANAWIYAH
}

\author{
DEVELOPMENT OF SCIENCE ENCYCLOPEDIA BASED ON INTEGRATION- \\ INTERCONNECTION OF ISLAM-SCIENCE AS A SELF-LEARNING RESOURCES FOR \\ MADRASAH TSANAWIYAH STUDENTS
}

\author{
Robi'ah Adwaiyah $^{1 *}$, Ika Kartika ${ }^{2}$ \\ ${ }^{1}$ Universitas Negeri Yogyakarta, Indonesia \\ ${ }^{2}$ Universitas Islam Negeri Sunan Kalijaga, Indonesia \\ robiahadawiyah.2018@student.uny.ac.id
}

\begin{abstract}
The dichotomy of natural science and religion is a problem in Madrasas. The availability of learning resources in schools, especially madrasah tsanawiyah, which facilitates the integration and interconnection of Islam and science, is still very minimal, so teachers still have difficulty instilling Islamic values. This study aimed, 1) to produce a science encyclopedia product based on the integrationinterconnection of Islam-science, 2) to know the quality of the science encyclopedia that has been developed, 3) to find out the responses of students and the implementation of the developed science encyclopedia. This research was development research. A 4-D model includes four stages: Define, Design, Develop, and Disseminate, which was used and limited to the Develop stage only. The research instruments were validation sheets, encyclopedia quality assessment sheets, and student response sheets. The results obtained that the quality of the development of science encyclopedias based on the integration-interconnection of Islamic science, the integration process of science material into verses of the Qur'an and hadith using an informative model is included in the Very Good classification based on the assessment of subject experts, linguists and graphic experts, integration-interconnection of Islamic science experts and science teachers. Students' responses to the limited test and broad test obtained was in the Agree classification.
\end{abstract}

Keywords: Science encyclopedia; Islamic-science integration; self-learning resources

\begin{abstract}
Abstrak
Dikotomi pembelajaran ilmu alam dan agama menjadi permasalahan di Madrasah. Ketersediaan sumber belajar di sekolah terutama madrasah tsanawiyah yang memfasilitasi integrasi-interkoneksi Islam dan sains masih sangat minim, sehingga guru masih kesulitan menanamkan nilai-nilai keislaman. Penelitian ini bertujuan, 1) menghasilkan produk ensiklopedia IPA berbasis integrasi-interkoneksi Islam-sains, 2) mengetahui kualitas ensiklopedia IPA yang telah dikembangkan, 3) mengetahui respon peserta didik dan keterlaksanaan ensiklopedia IPA yang telah dikembangkan. Penelitian ini adalah penelitian pengembangan. Menggunakan model 4-D meliputi 4 tahap: Define, Design, Develop, dan Disseminate yang dibatasi sampai tahap Develop. Instrumen penelitian berupa lembar validasi, lembar penilaian kualitas ensiklopedia, dan lembar respon peserta didik. Hasil diperoleh bahwa kualitas pengembangan ensiklopedia IPA berbasis integrasi-interkoneksi Islam sains, proses pengintegrasian dari materi IPA ke ayat Al-Qur'an dan hadis menggunakan model informatif termasuk kedalam klasifikasi Sangat Baik (SB) berdasarkan penilaian ahli materi, ahli bahasa dan grafika, ahli integrasi-interkoneksi Islam sains dan guru IPA. Respon peserta didik pada uji terbatas dan uji luas memperoleh klasifikasi Setuju (S).
\end{abstract}

Kata Kunci: Ensiklopedia IPA; keterpaduan Islam-sains; sumber balajar mandiri

Permalink/DOI: http:// doi.org/10.15408/es.v13i1.12970 


\section{PENDAHULUAN}

Dikotomi antara ilmu agama dan ilmu pengetahuan alam menjadikan kedua ilmu tersebut memiliki kesenjangan dan seolah tidak pernah bisa dipersatukan (M.Nurhadi Amri, Al Rasyidin, 2017; Umam, 2020). Adanya dikotomi ini karena proses pembelajaran pada umumnya memisahkan antara ilmu sains dan ilmu agama (Erdawati, 2018). Menurut (Makmun, 2014) keadaan ini dapat mengakibatkan peserta didik memiliki kepribadian yang tidak seimbang antara aspek kematangan karakter dan aspek intelektualnya. Kondisi ini juga dikarenakan materi pembelajaran yang saat ini berkembang dan diterapkan untuk mengajar di sekolah memisahkan antara kedua ilmu tersebut, bahkan khususnya di sekolah-sekolah madrasah (Erdawati, 2018). Padahal, penanaman nilai-nilai keislaman dalam proses pembelajaran khususnya ilmu pengetahuan alam berdasarkan kandungan AlQur'an dan hadis menjadi sangat penting.

Ilmu agama dan IPA pada dasarnya saling berkaitan dan dapat digabungkan salah satunya menggunakan integrasi-interkoneksi (Erdawati, 2018; M.Nurhadi Amri, Al Rasyidin, 2017; Makmun, 2014). Integrasi-interkoneksi adalah penyatuan dua atau lebih ilmu pengetahuan sehingga tidak berdiri sendiri yang tujuannya untuk saling menguatkan dan memperkaya pengetahuan (Abdullah, 2006; Masyitoh, Mustika, Alfaza, A.F., \& Hasyim, 2020). Integrasi-interkoneksi Islam dan sains menjadi solusi untuk menanamkan konsep dan nilai-nilai keislaman yang terdapat di dalam AlQuran kepada peserta didik, khususnya di sekolah madrasah (Kartika \& Ibrahim, 2020; Sholihah \& Kartika, 2018). Integrasi-interkoneksi disini bukan berarti peleburan antara sains dan Al-Quran menjadi satu, namun terkaitnya satu pengetahuan melalui satu hubungan yang saling membangun (Masyitoh et al., 2020). Oleh karena itu, diperlukan sumber belajar yang mendukung untuk mewujudkan keberhasilan proses pembelajaran integrasi-interkoneksi.

Observasi penelitian yang telah dilakukan Erdawati, (2018); Kartika \& Ibrahim, (2020); Makmun, (2014); Sholihah \& Kartika, (2018); dan Winarti, (2017) menyatakan bahwa sumber belajar berbasis integrasi interkoneksi pada sekolah madrasah masih terbatas. Pentingnya pengembangan sumber belajar berbasis integrasiinterkoneksi untuk memperkaya informasi peserta didik akan membantu guru menyusun bahan ajar, dan memudahkan peserta didik untuk mempelajari keterpaduan Islam dan sains.

Sumber belajar adalah segala sesuatu yang dapat digunakan untuk memfasilitasi kegiatan belajar, berupa segala jenis media cetak, media elektronik, benda, data, fakta, ide, orang, dan lainlain yang dapat mempermudah terjadinya proses belajar bagi peserta didik (Mulyatiningsih, 2013; Prastowo, 2011, 2013, 2014). Sayangnya penggunaan sumber belajar yang terintegrasi masih sangat minim.

Penyediaan sumber belajar yang memadai dan sesuai dengan level pengetahuan peserta didik memudahkan peserta didik dalam memahami pelajaran. Peserta didik tingkat MTs/SMP (usia 1115 tahun) menurut teori perkembangan Jean Piaget berada pada tahap perkembangan intelektual operasional konkret menuju operasional formal. Tahap perkembangan intelektual operasional konkret ditandai dengan perkembangan pola pikir yang holistik (menyeluruh) (Ibda, 2015). Pada tahap ini peserta didik sudah dapat belajar secara mandiri dan dapat berpikir secara ilmiah (Ibda, 2015).

Proses berpikir ilmiah, yaitu proses berpikir secara luas dengan pengertian yang lebih kompleks disertai pembuktian-pembuktian logis dan empiris (Rijal \& Sere, 2017). Sumber belajar berorientasi pada peserta didik secara individual dapat memfasilitasi peserta didik belajar secara mandiri (Cahyawulan \& Rachmawati, 2018; Roenah dan I. Kartika, 2019; Sholihah \& Kartika, 2018; Winarti \& Saputri, 2013). Hal ini juga mengingat bahwa orientasi kegiatan pembelajaran modern adalah berpusat pada peserta didik (Prastowo, 2011).

Di salah satu sekolah Madrasah Tsanawiyah di kota Yogyakarta (MTs Ibnul Qoyyim) menunjukkan perlunya pengembangan sumber belajar yang membantu siswa mengaitkan nilai keislaman dengan pengetahuan alam. Hasil observasi didapatkan guru IPA di sekolah tersebut telah mengaitkan pengetahuan sains dengan ayat- 
ayat Al-Qur'an dan nilai keislaman melalui proses pembelajaran secara langsung yang dipadukan dengan Al-Qur'an terjemahan. Hasil konfirmasi peserta didik dengan analisis angket pada tiga kelas (kelas VII, VII, dan IX) didapatkan proses pembelajaran yang menggunakan sumber belajar tunggal berupa buku paket IPA. Data lainnya berupa gaya belajar peserta didik menunjukkan $73,3 \%$ memiliki gaya belajar mandiri dengan penuh konsentrasi. Sedangkan $97,8 \%$ peserta didik menunjukkan kesukaan pada sumber belajar yang disertai gambar dan ilustrasi yang menarik dibandingkan bacaan teks yang panjang. Dengan demikian dapat diasumsikan perlunya penunjang pembelajaran berupa sumber belajar mandiri yang menarik dan memuat keterpaduan Islam dan sains di MTs.

Menurut (Prastowo, 2014), ensiklopedia merupakan salah satu sumber belajar yang digunakan secara mandiri. Ensiklopedia dijadikan sumber belajar alternatif untuk memberikan informasi yang akurat dan terbaru.

Kelebihan ensiklopedia dibandingkan dengan sumber belajar cetak lainnya yaitu pada menyajikan informasi secara mendasar dan lengkap dalam bidang ilmu (Cahyawulan \& Rachmawati, 2018; Erviana, 2019; Kartika \& Ibrahim, 2020). Ensiklopedia menurut (Tantriadi, 2013), mampu memberikan visualisasi yang dapat menarik minat peserta didik dalam proses pembelajaran. Salah satu ensiklopedia yang telah berhasil dikembangkan oleh (Khamdani, 2014), yaitu ensiklopedia fisika berbasis integrasi Islam-sains sebagai sumber belajar mandiri peserta didik SMA/MA memperoleh kategori sangat baik dan layak digunakan sebagai sumber belajar.

Keberadaan ensiklopedia sebagai bahan referensi penunjang menjadi penting untuk dikembangkan. Ensiklopedia yang dikembangkan diharapkan dapat menambah pengetahuan peserta didik terkait integrasi-interkoneksi Islam-sains. Oleh karena itu, tujuan penelitian ini adalah untuk mengembangkan ensiklopedia yang berbasis integrasi-interkoneksi antara Islam dan sains, mengetahui kualitas ensiklopedia, dan mengetahui respon peserta didik terhadap ensiklopedia yang telah dikembangkan untuk belajar mandiri.

\section{METODE}

Penelitian ini merupakan penelitian pengembangan, yaitu mengembangkan dan menghasilkan suatu produk yang kemudian divalidasi atau diuji kelayakannya sehingga dapat digunakan dalam proses pembelajaran (Sugiyono, 2015). Metode pengembangan dalam penelitian ini menggunakan pendekatan model 4-D (four-D model) yang dikemukakan oleh Sivasailam Thiagarajan, Dorothy S. Sammel, dan Melvyn I. Sammel (1974). Model ini terdiri dari 4 tahap pengembangan, yaitu: pendefinisian (Define), perancangan (Design), pengembangan (Develop), dan penyebaran (Disseminate)(Nursyahidah, 1989; Thiagarajan, S., Semmel, D. S \& Semmel, 1974).

Keempat tahapan tersebut kemudian disesuaikan dengan kebutuhan penelitian. Tahapan dalam penelitian ini dibatasi sampai pada tahap develop pada langkah developmental testing, hal ini disesuaikan dengan tujuan yang akan dicapai dalam penelitian (Mulyatiningsih, 2013). Tahapan akhir yang sesuai dengan tujuan pada penelitian ini adalah uji coba luas yang merupakan bagian dari tahapan develop pada langkah developmental testing. Adapun tahapan pengembangan produk pada penelitian ini dijabarkan sebagai berikut.

Tahap Define atau pendefinisian meliputi analisis kebutuhan, analisis peserta didik, dan analisis konsep. Analisis kebutuhan bertujuan untuk menentukan permasalahan dasar yang dihadapi dalam proses pembelajaran, sehingga diperlukan suatu pengembangan bahan ajar. Analisis peserta didik dilakukan untuk mendapatkan gambaran karakteristik peserta didik, meliputi: tingkat perkembangan intelektual dan keterampilan peserta didik. Analisis konsep dilakukan untuk mengidentifikasikan konsep pokok yang dikembangkan dalam bahan ajar.

Tahapan yang kedua adalah Design atau perancangan meliputi pemilihan format, desain awal ensiklopedia, dan produk I ensiklopedia. Pemilihan format bertujuan untuk menentukan model bahan ajar yang dikembangkan sesuai dengan kriteria yang kriteria menarik, memudahkan, dan membantu peserta didik dalam proses pembelajaran Sains-Al Qur'an. Guna 
memenuhi kriteria tersebut berdasarkan beberapa sumber dan informasi yang diperoleh dipilih jenis sumber belajar berupa ensiklopedia. Hasil pengembangan pertama yang dilakukan pada tahapan ini kemudian menjadi produk I ensiklopedia.

Tahap Develop atau tahap pengembangan, meliputi validasi dan revisi, penilaian kualitas, uji coba terbatas dan revisi produk, uji coba luas dan produk akhir. Validasi dilakukan untuk mendapatkan masukan dan saran dari validator terkait dengan format, bahasa, ilustrasi, dan isi dari ensiklopedia yang telah dikembangkan. Validasi dilakukan oleh para validator ahli, yaitu: ahli materi, ahli bahasa dan grafika, serta ahli integrasiinterkoneksi. Hasil dari validasi yang dilakukan oleh para ahli berupa saran dan masukan kemudian digunakan untuk merevisi ensiklopedia. Setelah direvisi selanjutnya ensiklopedia dinilai kembali oleh ahli materi, ahli bahasa dan grafika, ahli integrasi-interkoneksi, dan guru IPA SMP/MTs untuk mengetahui kualitas ensiklopedia. Uji coba dilakukan kepada peserta didik kelas VII MTs Ibnul Qoyim melalui dua tahap.

Uji coba tahap pertama adalah uji coba terbatas untuk mengetahui respon awal peserta didik terhadap ensiklopedia yang telah dikembangkan. Responden uji coba terbatas adalah 10 orang siswa MTs Ibnul Qoyim. Hasil saran dan masukan uji coba terbatas digunakan untuk menyempurnakan ensiklopedia. Uji coba tahap kedua adalah uji coba luas untuk mengetahui respon siswa terhadap ensiklopedia yang telah dikembangkan. Responden uji coba luas sebanyak 56 siswa MTs Ibnul Qoyim. Jika masih ada kekurangan pada ensiklopedia, maka dilakukan revisi perbaikan. Hasil revisi tersebut merupakan produk akhir ensiklopedia.

Teknik pengumpulan data pada penelitian ini adalah non-tes. Instrumen yang digunakan untuk mengumpulkan data berupa angket penelitian yang terdiri dari: lembar validasi, lembar penilaian kualitas, lembar respon peserta didik, dan lembar observasi keterlaksanaan ensiklopedia. Analisis penilaian kualitas ensiklopedia menggunakan skala Likert empat skala, yaitu 4: Sangat Baik (SB), 3:
Baik (B), 2: Tidak Baik (TB), dan 1: Sangat Tidak Baik (STB)(Widoyoko, 2012).

Tabel 1. Kriteria kategori penilaian kualitas ensiklopedia IPA

\begin{tabular}{ll}
\hline Skor rata-rata & Klasifiksi \\
\hline $3,25<\bar{X} \leq 4,00$ & Sangat Baik (SB) \\
$2,50<\bar{X} \leq 3,25$ & Baik (B) \\
$1,75<\bar{X} \leq 2,50$ & Tidak Baik (TB) \\
$1,00<\bar{X} \leq 1,75$ & Sangat Tidak Baik (STB) \\
\hline
\end{tabular}

Penggunaan skala empat dikarenakan skala empat mempunyai variabilitas respon lebih baik dibandingkan skala tiga, sehingga mampu mengungkap lebih maksimal (Widoyoko, 2012). Selain itu juga tidak ada peluang bagi responden untuk bersifat netral (kecenderungan memilih alternatif tengah). Data yang diperoleh kemudian dianalisis dengan menghitung nilai rata-rata setiap aspek. dengan persamaan sebagai berikut (Arikunto, 2013):

$$
\begin{aligned}
& \bar{X}=\frac{\sum X}{N \cdot n} \\
& \bar{X} \text { : skor rata-rata penilaian } \\
& \sum X \text { : jumlah skor penilaian } \\
& \mathrm{N} \quad \text { : jumlah penilai } \\
& \mathrm{n} \quad \text { : jumlah butir pernyataan }
\end{aligned}
$$

Analisis respon peserta didik dengan skala Guttman dua skala (Tabel 2) menggunakan pernyataan positif dan negatif dengan kategori Setuju (S) dan Tidak Setuju (TS). Skala pengukuran tipe ini akan di dapat jawaban yang jelas (tegas) dan konsisten (Widoyoko, 2012).

Tabel 2. Skor Respon Skala Guttman

\begin{tabular}{lll}
\hline Pernyataan & Skor \\
\cline { 2 - 3 } & S & TS \\
\hline Positif & 1 & 0 \\
Negatif & 0 & 1 \\
\hline
\end{tabular}

Selain menggunakan angket respon siswa, pada tahap uji luas terdapat dua observer yang bertugas mengamati proses jalannya uji coba luas. Kedua observer diberikan lembar observasi yang berisi pernyataan terkait pengamatan pada jalannya uji coba luas untuk mengetahui kualitas dan keterlaksanaan proses pembelajaran menggunakan ensiklopedia. 


\section{HASIL DAN PEMBAHASAN}

Penelitian ini menghasilkan produk berupa ensiklopedia IPA berbasis integrasi-interkoneksi Islam sains, yang dikembangkan berdasarkan model kajian informatif sesuai dengan model integrasi-interkoneksi yang dikembangkan oleh $\mathrm{M}$. Amin Abdullah. Model informatif berarti suatu disiplin ilmu perlu diperkaya dengan informasi yang dimiliki oleh disiplin ilmu lain sehingga dapat memperkaya wawasan dan ilmu pengetahuan (Abdullah, 2006). Hal ini sejalan dengan penelitian yang telah dilakukan oleh (Sholihah \& Kartika, 2018)menggunakan model informatif dapat membantu peserta didik menambah wawasan pengetahuan terkait dengan keterpaduan Islam dan sains. Adapun hasil dari penelitian yang telah dilakukan adalah sebagai berikut.

\section{Pendefinisian (Define)}

Tahap Define atau pendefinisian meliputi analisis kebutuhan, analisis peserta didik, dan analisis konsep. Data pada tahap pendefinisian diperoleh dari analisis hasil observasi, wawancara dan studi literatur. Beberapa hasil dari analisis kebutuhan pada tahap pendefinisian ditampilkan pada Tabel 3.

Tabel 3. Data hasil observasi, wawancara, dan studi literatur

\begin{tabular}{|c|c|}
\hline Kegiatan & Hasil \\
\hline $\begin{array}{l}\text { Analisis } \\
\text { kebutuhan }\end{array}$ & $\begin{array}{l}\text { 1. Hasil observasi proses pembelajaran di } \\
\text { kelas guru mengaitkan pembelajaran } \\
\text { dengan nilai-nilai keislaman. } \\
\text { 2. Selama di kelas guru mencoba } \\
\text { mengaitkan materi pelajaran IPA } \\
\text { dengan nilai keislaman dengan bantuan } \\
\text { Al-Quran terjemah. Belum ada sumber } \\
\text { belajar IPA yang memuat nilai-nilai } \\
\text { keislaman. } \\
\text { 3. Peserta didik lebih bersemangat dan } \\
\text { termotivasi ketika pembelajaran } \\
\text { dikaitkan dengan contoh nyata dalam } \\
\text { kehidupan sehari-hari dan nilai-nilai } \\
\text { keislaman. } \\
\text { 4. Hasil observasi sarana-prasarana yaitu } \\
\text { buku-buku di perpustakaan sekolah } \\
\text { buku sebagai sumber belajar yang } \\
\text { mengaitkan nilai keislaman masih } \\
\text { minim, hanya ada beberapa kitab tafsir } \\
\text { Al-quran. }\end{array}$ \\
\hline $\begin{array}{l}\text { Analisis } \\
\text { peserta } \\
\text { didik }\end{array}$ & $\begin{array}{l}\text { 1. Peserta didik berusia antara 11-15 } \\
\text { tahun } \\
\text { 2. Peserta didik menyukai proses belajar }\end{array}$ \\
\hline
\end{tabular}

mandiri

3. Peserta didik mempelajari mata pelajaran umum dan mata pelajaran keislaman

Analisis 1. Analisis materi IPA yang akan dimuat

konsep dalam ensiklopedia IPA akan dilakukan dengan cara mengumpulkan kata kunci informasi yang ada di beberapa buku IPA MTs. Melalui kata kunci yang telah ditemukan ini kemudian akan dikembangkan isi ensiklopedia berupa materi dan informasi.

2. Model integrasi-interkoneksi yang digunakan dalam ensiklopedia ini adalah model informatif. Proses pengintegrasian dilakukan dari materi IPA ke ayat Al-Qur'an dan hadis, yaitu materi dan informasi IPA yang telah ditemukan diintegrasikan dengan ayat Al-Qur'an dan hadis.

3. Ensiklopedia ini dibuat dengan bantuan perangkat lunak Microsoft word dan Corel DRAW X8

Setelah tahap pendefinisian selesai kemudian langkah selanjutnya dilakukan tahap perancangan.

\section{Perancangan (Design)}

Tahapan yang kedua adalah Design atau perancangan meliputi pemilihan format, desain awal ensiklopedia, dan produk I ensiklopedia. Tahap pemilihan format menghasilkan format rancangan ensiklopedia berupa: format penulisan, format isi, serta format desain dan tampilan. Setelah pemilihan format kemudian dibuat desain awal ensiklopedia sesuai dengan format yang telah ditentukan. Hasil dari desain awal ensiklopedia adalah produk I ensiklopedia. Sampul dari produk I ensiklopedia dapat dilihat pada Gambar 1.

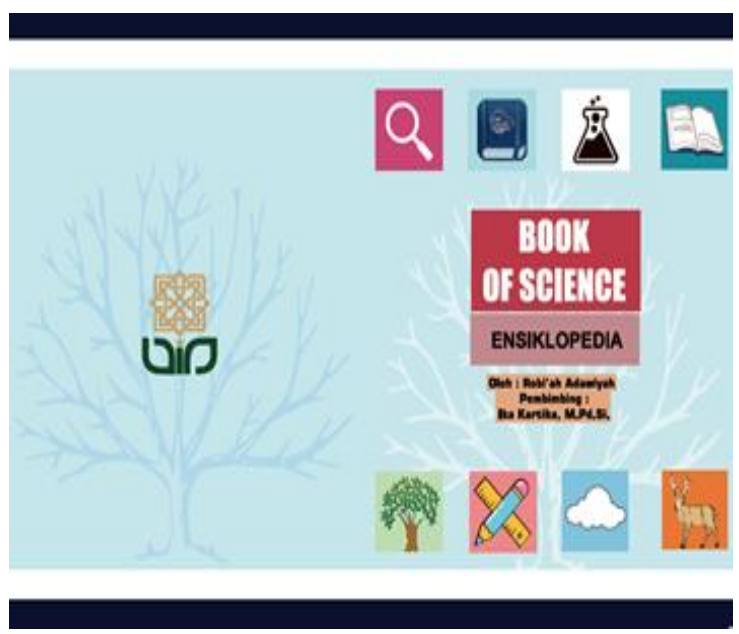

Gambar 1. Sampul produk I ensiklopedia

Ensiklopedia ini dibuat sesuai rumpun ilmu IPA yang memuat tiga materi, yaitu: fisika, kimia 
dan biologi. Integrasi-interkoneksi Islam sains berupa ayat Al-Quran dan hadis termuat dalam masing-masing materi secara informatif. Ayat AlQuran dan hadis disisipkan ke dalam materi atau melalui tambahan informasi yang diberi judul khusus wawasan keislaman seperti pada Gambar 2. Selain ayat Al-Quran dan hadis, di dalam ensiklopedia juga ditambahkan kotak info yang memuat informasi tentang ilmuwan-ilmuwan muslim terkenal. Setelah produk I ensiklopedia berhasil dibuat selanjutnya produk siap divalidasi oleh ahli pada tahap perancangan. Berikut hasil rancangan produk I ensiklopedia:

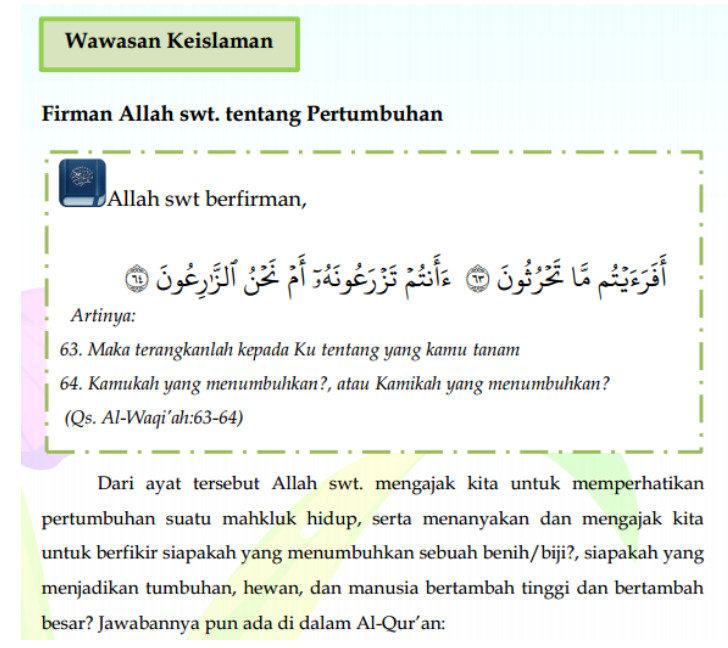

Gambar 2. Wawasan Keislaman

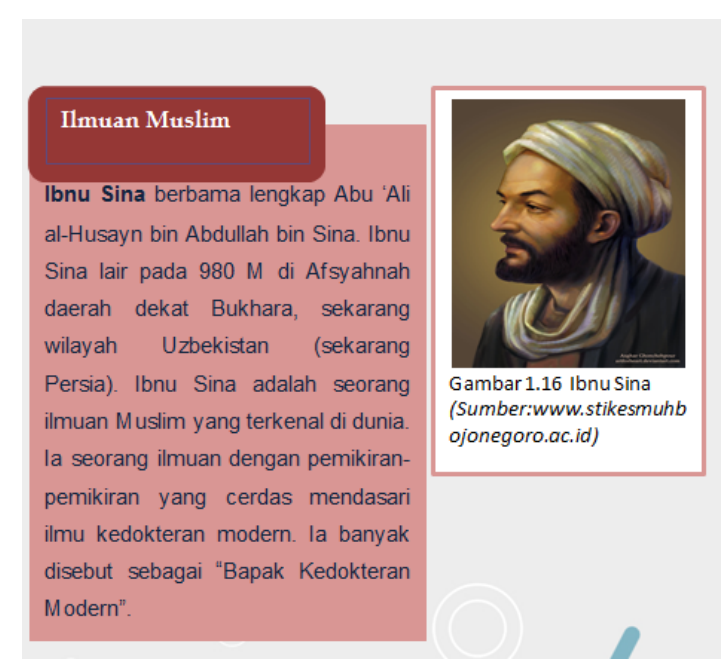

Gambar 3. Kotak info ilmuwan muslim

\section{Pengembangan (Develop)}

Tahap Develop atau tahap pengembangan, meliputi validasi dan revisi, penilaian kualitas, uji coba secara terbatas dan revisi produk, uji coba secara luas dan produk akhir. Hasil validasi adalah data kuantitatif atau kualitatif berupa masukan dan saran yang diperoleh dari validator ahli (Adawiyah, Istiyono, Wilujeng, \& Hardiyanti, 2020; Erviana, 2019). Terdapat tiga validator ahli yang memvalidasi ensiklopedia IPA berbasis integrasiinterkoneksi Islam-sains. Pertama, validasi yang dilakukan oleh ahli materi. Ahli materi memvalidasi ensiklopedia IPA berbasis integrasiinterkoneksi Islam sains terkait dengan keabsahan/kebenaran materi IPA yang terdiri dari fisika, kimia dan biologi. Hasil validasi berupa kritik dan saran dapat dilihat pada Tabel 4.

Tabel 4.Kritik dan saran validator ahli materi

\begin{tabular}{lcl}
\hline Validator & Kritik dan Saran & \\
\hline Ahli Materi & 1. & $\begin{array}{l}\text { Konsistensi penulisan simbol } \\
\text { besaran dan satuan harus } \\
\text { diperhatikan. }\end{array}$ \\
2. & $\begin{array}{l}\text { Pembenaran dari beberapa } \\
\text { konsep sains dan contohnya. }\end{array}$ \\
3. & $\begin{array}{l}\text { Perlu ditambahkan beberapa } \\
\text { gambar untuk memperjelas } \\
\text { konsep. }\end{array}$ \\
\hline
\end{tabular}

Kedua, validasi oleh ahli bahasa dan grafika. Ahli bahasa dan grafika memvalidasi ensiklopedia IPA berbasis integrasi-interkoneksi Islam-sains untuk mengetahui kesesuaian ensiklopedia IPA dari aspek bahasa dan kegrafikan. Hasil validasi yang berupa kritik dan saran dapat dilihat pada Tabel 5.

Tabel 5. Kritik dan saran validator ahli bahasa dan grafika

\begin{tabular}{|c|c|}
\hline Validator & Kritik dan Saran \\
\hline \multirow[t]{5}{*}{$\begin{array}{l}\text { Ahli Bahasa } \\
\text { dan Grafika }\end{array}$} & $\begin{array}{l}\text { 1. Perlu dilakukan perbaikan pada } \\
\text { desain sampul agar tidak terlihat } \\
\text { sederhana }\end{array}$ \\
\hline & $\begin{array}{l}\text { 2. Perlu mengganti gambar/foto yang } \\
\text { pecah/tidak jelas }\end{array}$ \\
\hline & $\begin{array}{l}\text { 3. Penggunaan kata hubung } \\
\text { antarkalimat perlu diperbaiki }\end{array}$ \\
\hline & $\begin{array}{l}\text { 4. Perlu perbaikan pada penggunaan } \\
\text { ukuran huruf pada judul }\end{array}$ \\
\hline & $\begin{array}{l}\text { 5. Jenis huruf untuk judul bab, } \\
\text { sebaiknya menggunakan huruf tebal }\end{array}$ \\
\hline
\end{tabular}

\begin{tabular}{clll}
\hline Ketiga, & validasi oleh ahli & integrasi- \\
interkoneksi & Islam-sains. & Ahli & integrasi-
\end{tabular} interkoneksi Islam sains memvalidasi ensiklopedia IPA berbasis integrasi-interkoneksi Islam sains untuk mengetahui kesesuaian integrasi-interkoneksi dengan ayat $\mathrm{Al}$-Qur'an dan hadis serta kesesuaian model integrasi-interkoneksi yang digunakan. Hasil validasi yang berupa kritik dan saran dapat dilihat pada Tabel 6. 
Tabel 6. Kritik dan saran validator ahli integrasiinterkoneksi Islam sains

\begin{tabular}{|c|c|}
\hline Validator & Kritik dan Saran \\
\hline $\begin{array}{l}\text { Ahli } \\
\text { integrasi- } \\
\text { Interkoneksi }\end{array}$ & $\begin{array}{l}\text { 1. Perlu ditambahkan pengantar } \\
\text { untuk ayat yang tidak langsung } \\
\text { sesuai dengan materi/informasi }\end{array}$ \\
\hline Islam-Sains & $\begin{array}{l}\text { 2. Perlu dituliskan referensi } \\
\text { tafsir/sumber integrasi- } \\
\text { interkoneksi Islam sains antara } \\
\text { ayat Al-Quran dan hadis. }\end{array}$ \\
\hline
\end{tabular}

Hasil dari validator berupa saran dan masukan selanjutnya digunakan untuk perbaikan agar diperoleh produk ensiklopedia IPA yang benar-benar valid. Beberapa contoh hasil perbaikan berdasarkan masukan para ahli yang telah dilakukan pada tahap pengembangan dapat dilihat pada Gambar 4 sampai Gambar 7.

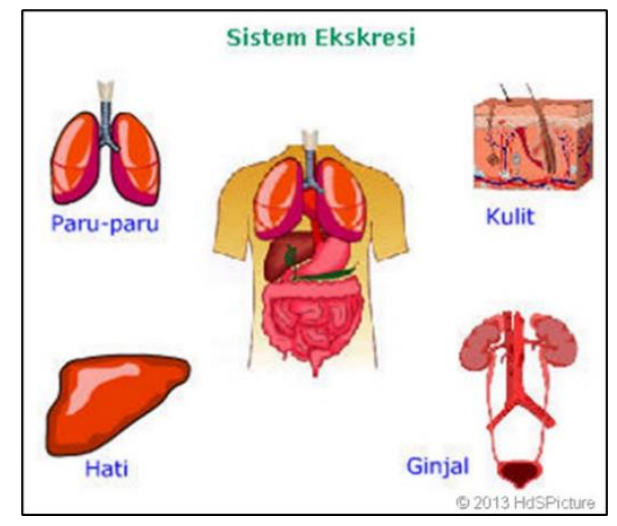

Gambar 4. Kualitas gambar kurang baik

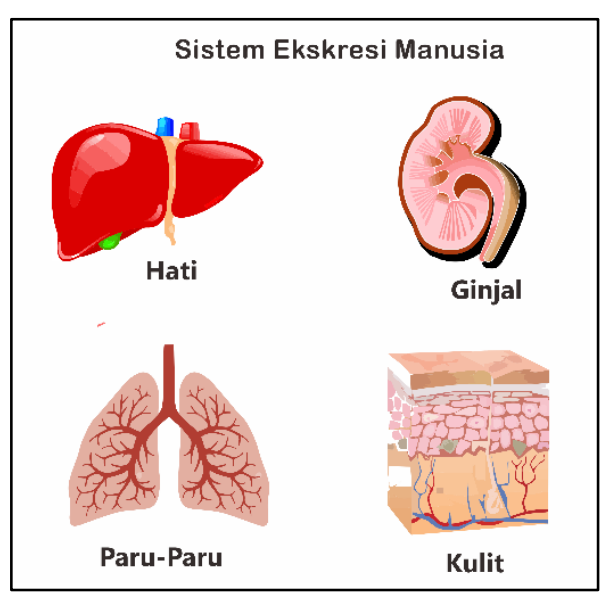

Gambar 5. Perbaikan gambar yang kurang baik

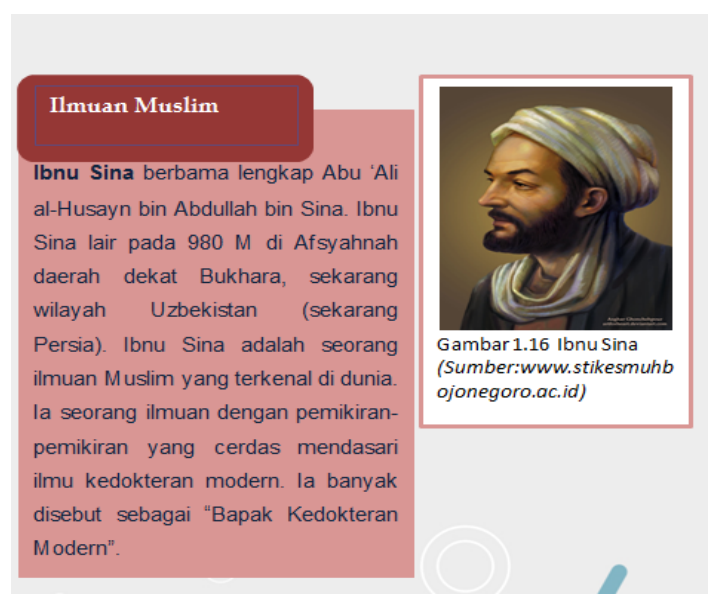

Gambar 6. Desain yang kurang sesuai

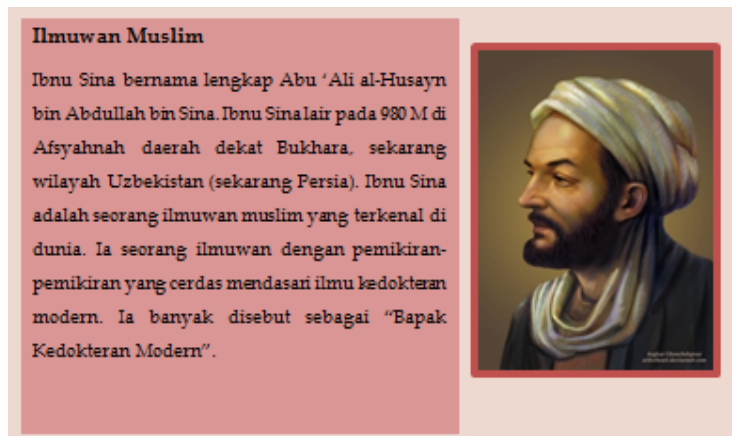

Gambar 7. Hasil perbaikan desain

Setelah melakukan perbaikan berdasarkan saran dan masukan dari para validator ahli kemudian diperoleh ensiklopedia yang valid, yang selanjutnya ensiklopedia di nilai oleh para ahli dan guru IPA.

\section{Data Hasil Penilaian Ensiklopedia}

Penilaian produk ensiklopedia dilakukan oleh ahli materi, ahli bahasa dan grafika, ahli integrasiinterkoneksi Islam sains dan guru IPA. Tujuan dari penilaian ini adalah untuk mengetahui kualitas ensiklopedia yang telah dikembangkan. Hasil penilaian yang telah dilakukan oleh para ahli kemudian dianalisiss dan diperoleh data kuantitatif seperti pada Tabel 7.

Tabel 7. Hasil Penilaian Ensiklopedia

\begin{tabular}{llll}
\hline No & Validator & Skor & Kategori \\
\hline 1 & Ahli Materi & 3,37 & Sangat Baik \\
2 & $\begin{array}{l}\text { Ahli bahasa } \\
\text { dan grafika }\end{array}$ & 3,41 & Sangat Baik \\
3 & $\begin{array}{l}\text { Ahli Integrasi- } \\
\text { Interkoneksi }\end{array}$ & 3,25 & Sangat Baik \\
4 & Guru IPA & 3,40 & Sangat Baik \\
\hline
\end{tabular}

Hasil penilaian oleh ahli materi dapat dilihat pada Tabel 7. Aspek yang dinilai oleh ahli materi meliputi aspek kelayakan materi/isi dan aspek 
penyajian. Penilaian ahli materi terhadap ensiklopedia IPA berbasis integrasi-interkoneksi Islam sains secara keseluruhan diperoleh skor ratarata 3,37 . Berdasarkan seluruh aspek yang dinilai, ensiklopedia IPA berbasis integrasi-interkoneksi menurut ahli materi memiliki klasifikasi kualitas sangat baik (SB).

Hasil penilaian oleh ahli grafika dapat dilihat pada Tabel 7. Aspek yang dinilai oleh ahli bahasa dan grafika meliputi aspek bahasa dan aspek kegrafikan. Penilaian ahli bahasa dan grafika terhadap ensiklopedia IPA berbasis integrasiinterkoneksi Islam sains secara keseluruhan diperoleh skor rata-rata 3,41. Berdasarkan aspek yang dinilai, ensiklopedia IPA berbasis integrasiinterkoneksi Islam sains menurut ahli bahasa dan grafika memiliki klasifikasi kualitas sangat baik (SB).

Hasil penilaian oleh ahli integrasiinterkoneksi dapat dilihat pada Tabel 7. Aspek yang dinilai oleh ahli integrasi-interkoneksi Islam sains meliputi aspek integrasi-interkoneksi dan model integrasi-interkoneksi Islam sains. Penilaian ahli integrasi-interkoneksi Islam sains terhadap ensiklopedia IPA berbasis integrasi-interkoneksi Islam sains secara keseluruhan diperoleh skor ratarata 3,50. Berdasarkan aspek yang dinilai, ensiklopedia IPA berbasis integrasi-interkoneksi Islam sains menurut ahli integrasi-interkoneksi Islam sains memiliki klasifikasi kualitas sangat baik (SB).

Hasil penilaian oleh guru IPA dapat dilihat pada Tabel 6. Aspek yang dinilai oleh guru IPA meliputi aspek kelayakan materi/isi, aspek penyajian, aspek bahasa, dan aspek kegrafikan. Penilaian guru IPA terhadap ensiklopedia IPA berbasis integrasi-interkoneksi Islam sains secara keseluruhan diperoleh skor rata-rata 3,40. Berdasarkan aspek yang dinilai, ensiklopedia IPA berbasis integrasi-interkoneksi Islam sains menurut guru IPA memiliki klasifikasi kualitas sangat baik (SB). Keempat hasil penilaian tersebut digambarkan pada Gambar 8.

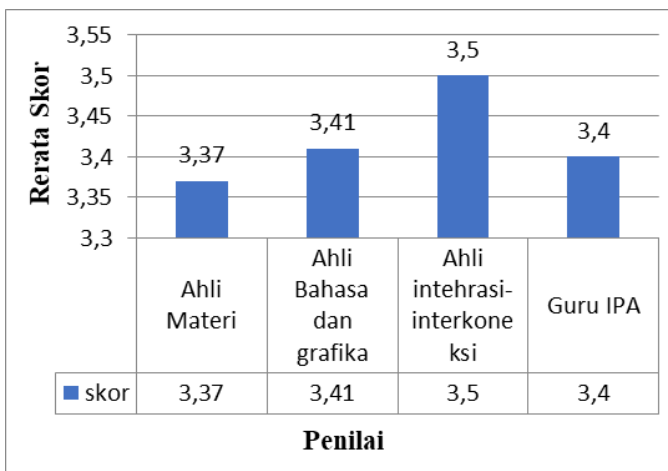

Gambar 8. Diagram hasil penilaian ahli dan guru IPA

\section{Hasil Respon Peserta Didik}

Respon peserta didik diperoleh dari uji coba terbatas dan uji coba luas dengan menggunakan lembar angket. Berdasarkan hasil uji coba terbatas yang telah dilaksanakan diperoleh skor rata-rata setiap aspek sebesar 0,97 untuk aspek penyajian, 0,88 untuk aspek bahasa, dan 1,00 untuk aspek isi. Secara keseluruhan respon yang diberikan oleh para responden terhadap ensiklopedia IPA berbasis integrasi-interkoneksi Islam-sains pada uji coba terbatas memberikan respon setuju (S). Hasil uji coba terbatas masing-masing aspek dapat dilihat pada Tabel 8 .

Tabel 8. Hasil Respon Peserta Didik Uji Coba Terbatas

\begin{tabular}{lll}
\hline Aspek yang Dinilai & Rerata Skor & Kategori \\
\hline Penyajian & 0,97 & Setuju \\
Bahasa & 0,88 & Setuju \\
Isi & 1,00 & Setuju \\
\hline
\end{tabular}

Uji coba luas dilakukan dengan memberikan lembar angket terhadap 25 responden, yaitu peserta didik untuk mendapatkan respon terhadap ensiklopedia IPA berbasis integrasi-interkoneksi Islam sains. Data yang diperoleh dari uji coba luas berupa skor rata-rata sebesar 0,95 untuk aspek penyajian, 0,92 untuk aspek bahasa, dan 0,99 untuk aspek isi. Secara keseluruhan respon yang diberikan oleh para responden terhadap ensiklopedia IPA berbasis integrasi-interkoneksi Islam-sains pada uji coba luas memberikan respon setuju (S). Data hasil uji coba luas dapat dilihat pada Tabel 9.

Tabel 9. Hasil Respon Peserta Didik Uji Coba Luas

\begin{tabular}{lll}
\hline Aspek yang Dinilai & Rerata Skor & Kategori \\
\hline Penyajian & 0,95 & Setuju \\
Bahasa & 0,92 & Setuju \\
Isi & 0,99 & Setuju \\
\hline
\end{tabular}


Hasil perbandingan respon peserta didik pada uji terbatas dan uji luas untuk ketiga aspek disajikan pada Gambar 9.

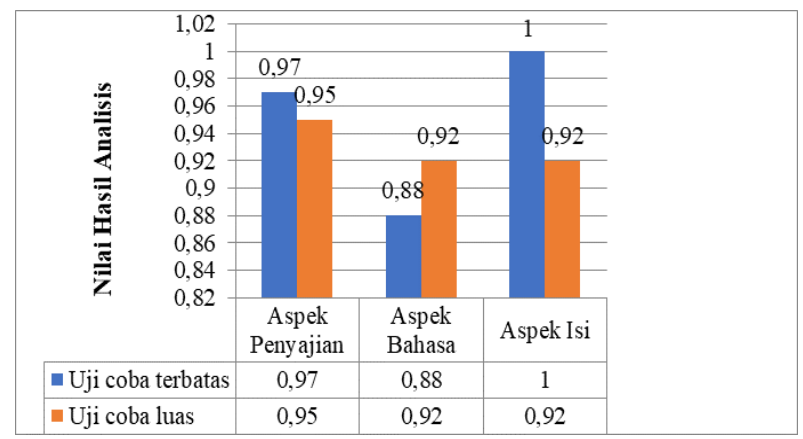

Gambar 9. Perbandingan respon peserta didik pada uji coba terbatas dan uji coba luas

Selain data kuantitatif dari hasil analisis angket peserta didik pada tahap uji coba luas terdapat dua observer yang mengobservasi jalannya proses uji coba luas. Adanya observer bertujuan untuk mengamati siswa saat belajar menggunakan ensiklopedia guna mengetahui kualitas ensiklopedia yang telah dikembangkan. Adapun hasil respon dan komentar dari observer pada tahap uji coba luas dapat dilihat pada Tabel 10 .

Tabel 10. Hasil observasi kualitas ensiklopedia

\begin{tabular}{|c|c|c|}
\hline Pernyataan & Observer & Hasil Pengamatan \\
\hline \multirow{8}{*}{$\begin{array}{l}\text { Ensiklopedia } \\
\text { menunjang } \\
\text { pembelajaran } \\
\text { mandiri bagi } \\
\text { peserta didik. }\end{array}$} & I & Ensiklopedia ini \\
\hline & & mempermudah peserta didik \\
\hline & & untuk belajar mandiri, \\
\hline & & berdasarkan hasil \\
\hline & & pengamatan pada uji luas \\
\hline & & $\begin{array}{l}\text { antusias peserta didik saat } \\
\text { membaca dan menggunakan }\end{array}$ \\
\hline & & $\begin{array}{l}\text { ensiklopedia terlihat sangat } \\
\text { tinggi. }\end{array}$ \\
\hline & II & $\begin{array}{l}\text { Materi yang dipaparkan } \\
\text { menarik dan mudah } \\
\text { dipahami peserta didik, } \\
\text { sehingga dapat digunakan } \\
\text { peserta didik untuk belajar } \\
\text { mandiri. }\end{array}$ \\
\hline \multirow{7}{*}{$\begin{array}{l}\text { Ensiklopedia } \\
\text { mampu } \\
\text { memberikan } \\
\text { peserta didik } \\
\text { kemudahan } \\
\text { dalam belajar } \\
\text { mandiri. }\end{array}$} & $\mathbf{I}$ & Ensiklopedia memuat \\
\hline & & materi yang mudah \\
\hline & & dipahami sehingga peserta \\
\hline & & didik dapat belajar mandiri \\
\hline & & tanpa bantuan pembimbing. \\
\hline & II & Sebagian besar siswa dapat \\
\hline & & $\begin{array}{l}\text { ensiklopedia, hanya ada } 3 \\
\text { orang peserta didik yang } \\
\text { bertanya terkait materi yang } \\
\text { kurang dipahami. }\end{array}$ \\
\hline \multirow[t]{2}{*}{$\begin{array}{l}\text { Ensiklopedia } \\
\text { dapat } \\
\text { digunakan } \\
\text { tanpa media } \\
\text { lain }\end{array}$} & $\mathbf{I}$ & $\begin{array}{l}\text { Peserta didik dapat belajar } \\
\text { hanya dengan menggunakan } \\
\text { ensiklopedia tanpa bantuan } \\
\text { media lain. }\end{array}$ \\
\hline & II & Ensiklopedia dapat \\
\hline
\end{tabular}

digunakan tanpa bergantung dengan media lain

Hasil dari pengamatan observer diketahui bahwa kualitas ensiklopedia sebagai sumber belajar dapat dikatakan baik, kemudian ensiklopedia dapat memfasilitasi proses belajar mandiri peserta didik.

Setelah melalui beberapa tahapan pengembangan, produk akhir yang telah berhasil dikembangkan pada penelitian ini adalah ensiklopedia IPA berbasis integrasi-interkoneksi Islam-sains.

Beberapa cuplikan isi dari ensiklopedia IPA berbasis integrasi-interkoneksi Islam-sains dapat dilihat pada Gambar 10 sampai dengan Gambar 12.

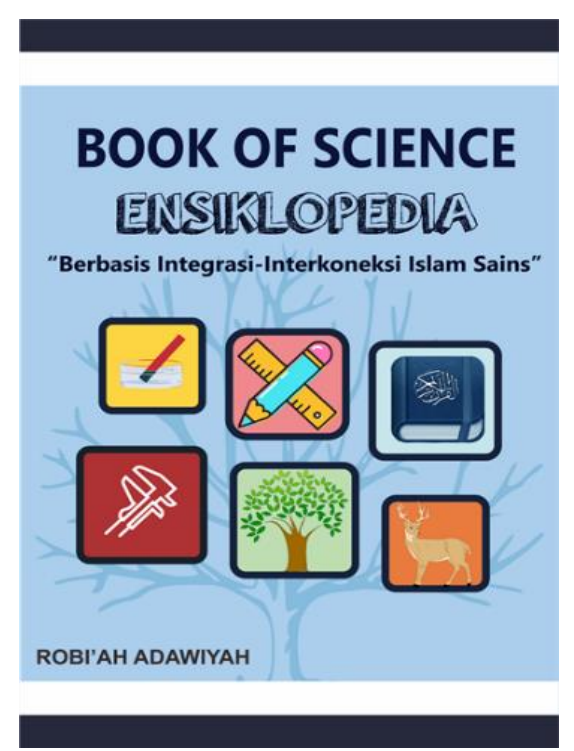

Gambar 10. Sampul Depan Ensiklopedia

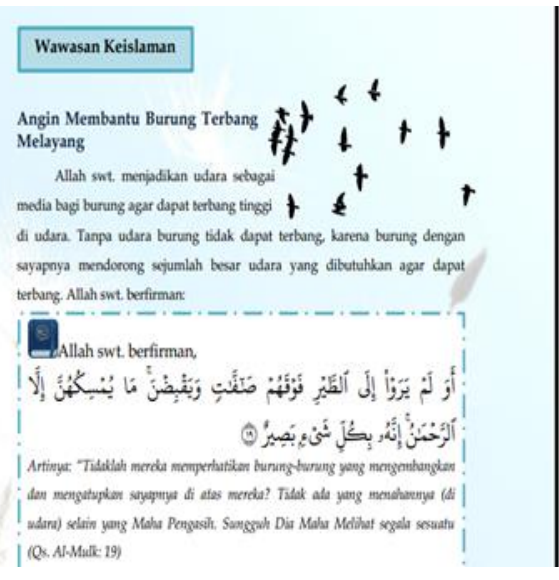

Gambar 11. Isi ensiklopedia wawasan keislaman 


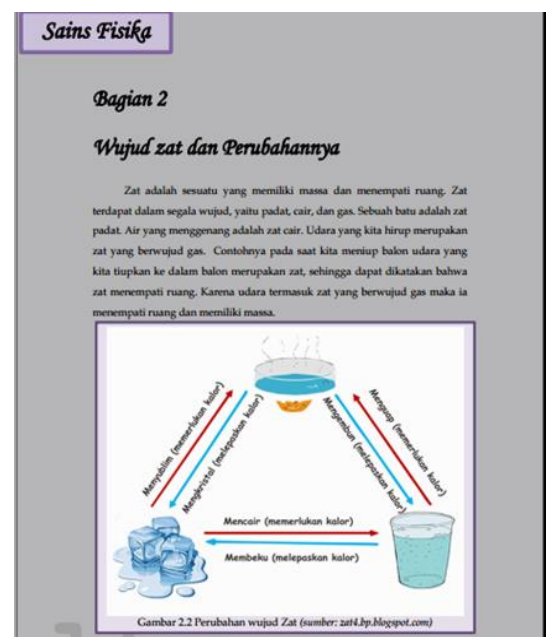

Gambar 12. Bagian Isi Materi Fisika

Gambar 10 merupakan sampul dari ensiklopedia. Gambar 11 merupakan cuplikan dari bagian ensiklopedia IPA yang menjelaskan integrasiinterkoneksi Islam-sains. Gambar 12 merupakan isi materi fisika yang disajikan dalam ensiklopedia. Selain memuat materi dan informasi, ensiklopedia IPA ini dilengkapi dengan tambahan informasi berupa wawasan sains, wawasan keislaman, informasi menarik dan kotak info yang tujuannya untuk memperkaya informasi yang diperoleh peserta didik.

Ensiklopedia IPA berbasis integrasiinterkoneksi menyajikan hal baru bagi peserta didik. Berdasarkan hasil pengamatan observer diketahui bahwa peserta didik sangat antusias dalam mengikuti proses pembelajaran dengan menggunakan sumber belajar ensiklopdia IPA berbasis integrasiinterkoneksi Islam-sains dan melahirkan rasa ingin tahu yang tinggi terhadap integrasi-interkoneksi Islam-sains. Hal ini senada dengan penelitian yang telah dilakukan oleh (Erviana, 2019) yang menyatakan bahwa ensiklopedia layak digunakan dalam proses pembelajaran.

Berdasarkan hasil penelitian dapat disimpulkan bahwa: 1) ensiklopedia IPA berbasis integrasiinterkoneksi Islam sains telah berhasil dikembangkan. Ensiklopedia dikembangkan menggunakan model integrasi interkoneksi informatif dengan proses pengintegrasian dari materi IPA ke ayat Al-Qur'an dan hadis. 2) kualitas ensiklopedia IPA berbasis integrasi-interkoneksi Islam sains berdasarkan hasil penilaian ahli materi, ahli bahasa dan grafika, ahli integrasi-interkoneksi, dan guru IPA dengan perolehan skor rata-rata secara berurutan 3,37; 3,41; 3,25; dan 3,40 ke semuanya tergolong dalam klasifikasi Sangat Baik (SB). 3) respon peserta didik terhadap ensiklopedia IPA berbasis integrasiinterkoneksi Islam sains pada uji coba terbatas dan uji coba luas memperoleh skor rata-rata 0,95 untuk uji coba terbatas dan 0,95 untuk uji coba luas yang keduanya tergolong dalam klasifikasi Setuju (S). Oleh karena itu dapat disimpulkan bahwa ensiklopedia IPA berbasis integrasi-interkoneksi yang telah dikembangkan dalam penelitian ini layak untuk digunakan sebagai sumber belajar.

Berdasarkan hasil penelitian dapat disimpulkan bahwa: 1) ensiklopedia IPA berbasis integrasiinterkoneksi Islam sains telah berhasil dikembangkan. Ensiklopedia dikembangkan menggunakan model integrasi interkoneksi informatif dengan proses pengintegrasian dari materi IPA ke ayat Al-Qur'an dan hadis. 2) kualitas ensiklopedia IPA berbasis integrasi-interkoneksi Islam sains berdasarkan hasil penilaian ahli materi, ahli bahasa dan grafika, ahli integrasi-interkoneksi, dan guru IPA dengan perolehan skor rata-rata secara berurutan 3,$37 ; 3,41$; 3,25 ; dan 3,40 ke semuanya tergolong dalam klasifikasi Sangat Baik (SB). 3) respon peserta didik terhadap ensiklopedia IPA berbasis integrasiinterkoneksi Islam sains pada uji coba terbatas dan uji coba luas memperoleh skor rata-rata 0,95 untuk uji coba terbatas dan 0,95 untuk uji coba luas yang keduanya tergolong dalam klasifikasi Setuju (S). Oleh karena itu dapat disimpulkan bahwa ensiklopedia IPA berbasis integrasi-interkoneksi yang telah dikembangkan dalam penelitian ini layak untuk digunakan sebagai sumber belajar.

\section{UCAPAN TERIMA KASIH}

Terima kasih kepada LPPM UIN Sunan Kalijaga yang telah membiayai penelitian ini melalui hibah dana penelitian. Terima kasih kepada kepala sekolah, guru, dan siswa MTs Ibnul Qoyim yang telah memberikan kesempatan kepada peneliti untuk melakukan penelitian menggunakan ensiklopedia IPA berbasis integrasi-interkoneksi Islam sains. Kepada peneliti yang akan melakukan penelitian lebih lanjut dapat meneliti tentang efektifitas atau pengaruh penggunaan ensiklopedia IPA berbasis integrasiinterkoneksi Islam sains terhadap variabel yang berbeda dengan latar belakang yang berbeda. 


\section{DAFTAR PUSTAKA}

Abdullah, M. A. (2006). Integrasi Ilmu dan Agama: Studi Atas Paradigma Integratif- Interkonektif UIN Sunan Kalijaga Yogjakarta. Yogyakarta: UIN SUKA Press.

Adawiyah, R., Istiyono, E., Wilujeng, I., \& Hardiyanti, S. (2020). Development of an instrument measuring the multi representation ability of senior high school students. Journal of Physics: Conference Series, 1440(1). https://doi.org/10.1088/17426596/1440/1/012028

Arikunto, S. (2013). Dasar-Dasar Evaluasi Pendidikan. Yogyakarta: Bumi Aksara.

Cahyawulan, W., \& Rachmawati, D. (2018). Pengembangan Ensiklopedia Pekerjaan Bidang Matematika dan Ilmu Pengetahuan Alam (MIPA) untuk Peserta Didik Kelas X di SMA Suluh Jakarta. INSIGHT: Jurnal Bimbingan Konseling, $\quad 7(2), \quad 140-146$. https://doi.org/10.21009/insight.072.03

Erdawati, S. (2018). Pengembangan Ensiklopedia IPA Berbasis Integrasi Islam Sains untuk Meningkatkan Motivasi Siswa Kelas IV SD Negeri 003 Enok Kecamatan Enok. Al-Aulia: Jurnal Pendidikan Dan Ilmu-Ilmu Keislaman, 4(1), 40-57.

Erviana, V. Y. (2019). Pengembangan Ensiklopedia Terintegrasi STEM (Science, Technology, Engineering, Mathematics) Sebagai Pengayaan Bagi Peserta Didik di Sekolah Dasar. Jurnal Inovasi Pendidikan Dasar, 5(1), 31-44. https://doi.org/10.22236/jipd.v5i1.96

Ibda, F. (2015). Perkembangan Kognitif: Teori Jean Piaget. Intelektualita, 3(1), 242904.

Kartika, I., \& Ibrahim, I. (2020). Efektivitas Ensiklopedia IPA Terintegrasi Al-Quran untuk Siswa Tunanetra. Inklusi, 7(2), 229. https://doi.org/10.14421/ijds.070203

Khamdani, S. L. (2014). Pengembangan Ensiklopedia Fisika Berbasis Integrasi-Interkoneksi IslamSains Sebagai Sumber Belajar Mandiri Siswa SMA/MA. Yogyakarta: UIN Sunan Kalijaga.

M.Nurhadi Amri, Al Rasyidin, A. I. (2017). Integrasi Nilai-Nilai Keislaman Dalam Pembelajaran Biologi di SMA Islam Al Ulum Terpadu Medan. Edu Riligia, 01, 487-501. Retrieved from

http://jurnal.uinsu.ac.id/index.php/eduriligia/art icle/download/1067/831
Makmun, M. N. Z. (2014). Pengembangan Pembelajaran IPA (Sains) Dan IPS di Madrasah Ibtidaiyah (Berbasis Integrasi Interkoneksi). TERAMPIL: Jurnal Pendidikan Dan Pembelajaran Dasar, 1(1), 79-98. Retrieved from http://ejournal.radenintan.ac.id/index.php/tera mpil/article/view/1307

Masyitoh, D., Mustika, R. D., Alfaza, A. S., A.F., H., \& Hasyim, U. A. F. A. (2020). Amin Abdullah dan Paradigma Integrasi Interkoneksi. Attractive: Innovative Education Journal, 2(1), 108-116. Retrieved from https://www.attractivejournal.com/index.php/aj I

Mulyatiningsih, E. (2013). Metode Penelitian Terapan Bidang Pendidikan. Bandung: Alfabeta.

Nursyahidah, F. (1989). Penelitian Pengembangan. Research and Development vs Development Research, 1-27.

Prastowo, A. (2011). Pengembangan Sumber Belajar. Yogyakarta: Fakultas Tarbiyah UIN Sunan Kalijaga.

Prastowo, A. (2013). Panduan Kreatif Membuat Bahan Ajar Inovatif. Yogyakarta: Diva Press.

Prastowo, A. (2014). Pengembangan Bahan Ajar Tematik: Tinjauan Teoritis dan Praktik. Jakarta: Kencana.

Rijal, M., \& Sere, I. (2017). Sarana Berfikir Ilmiah. Jurnal Biology Science \& Education, 6(2), 176-185.

Roenah dan I. Kartika. (2019). Pengembangan Modul IPA Berbasis Literasi Sains pada Materi Suhu, Pemuaian, dan Kalor untuk Peserta Didik SMP/MTs Kelas VII. JRPF: Jurnal Riset Pendidikan Fisika, 4(2), 91-97.

Sholihah, N., \& Kartika, I. (2018). Pengembangan Modul IPA Terintegrasi Dengan Ayat Al Qur'an Dan Hadis. Lentera Pendidikan: Jurnal Ilmu Tarbiyah Dan Keguruan, 21(1), $12-22$.

https://doi.org/10.24252/lp.2018v21n1i2

Sugiyono. (2015). Metode penelitian pendidikan pendekatan kuantitatif, kualitatif, dan $R \& D$. Bandung: Alfabeta.

Tantriadi, Y. (2013). Pembuatan Ensiklopedia Interaktif Tatasurya untuk Siswa SMP. Calyptra: Jurnal Ilmiah Mahasiswa Universitas Surabaya, 2(1). 